Article

\title{
Antibiofilm Activity of Acidic Phospholipase Isoform Isolated from Bothrops erythromelas Snake Venom
}

\author{
Ellynes Nunes ${ }^{1}$, Breno Frihling ${ }^{2}{ }^{(0)}$, Elizângela Barros ${ }^{2}$, Caio de Oliveira ${ }^{3}{ }^{\circledR}$, \\ Newton Verbisck $\left.{ }^{4}{ }^{(}\right)$, Taylla Flores ${ }^{1}$, Augusto de Freitas Júnior ${ }^{1}$, Octávio Franco ${ }^{2,5}{ }^{\circledR}$, \\ Maria de Macedo ${ }^{3}\left(\mathbb{D}\right.$, Ludovico Migliolo ${ }^{1,2,5, *(\mathbb{D})}$ and Karla Luna ${ }^{1,6}$ \\ 1 Postgraduate Program in Cellular and Molecular Biology—Federal University of Paraíba, João Pessoa, \\ PB 58051-900, Brazil; ellynesnunes@gmail.com (E.N.); taylla.flores@gmail.com (T.F.); \\ gutovfj@dbm.ufpb.br (A.d.F.J.); karlaceatox@yahoo.com.br (K.L.) \\ 2 S-Inova Biotech, Postgraduate Program in Biotechnology—Dom Bosco Catholic University, Campo Grande, \\ MS 79117-010, Brazil; brenoemanuelfarias@gmail.com (B.F.); elihbarros.you@gmail.com (E.B.); \\ ocfranco@gmail.com (O.F.) \\ 3 Protein Purification Laboratory and its Biological Functions, Faculty of Medicine, FAMED, Federal \\ University of Mato Grosso do Sul (UFMS), Campo Grande, MS 79603-011, Brazil; \\ oliveiracfr@gmail.com (C.d.O.); ligiamacedo18@gmail.com (M.d.M.) \\ 4 Embrapa Beef Cattle, Campo Grande, MS 79106-550, Brazil; newton.verbisck@embrapa.br \\ 5 Center for Proteomic and Biochemical Analysis, Graduate Program in Genomic Sciences and Biotechnology, \\ Catholic University of Brasilia, Brasilia 71966-700, Federal District, Brazil \\ 6 Center of Biological and Health Sciences, Postgraduate Program in Science and Mathematics Education, \\ Paraíba State University, Campina Grande PB 58429-500, Brazil \\ * Correspondence: ludovico@ucdb.br; Tel.: +55-067-98111-0495
}

Received: 2 July 2020; Accepted: 7 August 2020; Published: 20 Septembe 2020

\begin{abstract}
Introduction: Bacterial resistance is a worldwide public health problem, requiring new therapeutic options. An alternative approach to this problem is the use of animal toxins isolated from snake venom, such as phospholipases $\mathrm{A}_{2}\left(\mathrm{PLA}_{2}\right)$, which have important antimicrobial activities. Bothrops erythromelas is one of the snake species in the northeast of Brazil that attracts great medical-scientific interest. Here, we aimed to purify and characterize a $\mathrm{PLA}_{2}$ from B. erythromelas, searching for heterologous activities against bacterial biofilms. Methods: Venom extraction and quantification were followed by reverse-phase high-performance liquid chromatography (RP-HPLC) in C18 column, matrix-assisted ionization time-of-flight (MALDI-ToF) mass spectrometry, and sequencing by Edman degradation. All experiments were monitored by specific activity using a 4-nitro-3-(octanoyloxy) benzoic acid $\left(4 \mathrm{~N}_{3} \mathrm{OBA}\right)$ substrate. In addition, hemolytic tests and antibacterial tests including action against Escherichia coli, Staphylococcus aureus, and Acinetobacter baumannii were carried out. Moreover, tests of antibiofilm action against $A$. baumannii were also performed. Results: PLA ${ }_{2}$, after one purification step, presented $31 \mathrm{~N}$-terminal amino acid residues and a molecular weight of $13.6564 \mathrm{Da}$, with enzymatic activity confirmed in $0.06 \mu \mathrm{M}$ concentration. Antibacterial activity against $S$. aureus $\left(\mathrm{IC}_{50}=30.2 \mu \mathrm{M}\right)$ and antibiofilm activity against $A$. baumannii $\left(\mathrm{IC}_{50}=1.1 \mu \mathrm{M}\right)$ were observed. Conclusions: This is the first time that $\mathrm{PLA}_{2}$ purified from B. erythromelas venom has appeared as an alternative candidate in studies of new antibacterial medicines.
\end{abstract}

Keywords: bacterial resistance; animal venom; purification; antibacterial and antibiofilm activity

Key Contribution: Antibiofilm activity of phospholipase $\mathrm{A}_{2}$ isolated from snake venom was tested. $\mathrm{PLA}_{2}$ was isolated from B. erythromelas venom without hemolytic activity in murine blood. 


\section{Introduction}

With the increase in mortality, morbidity, and the rising demand for spending on diagnostic and therapeutic procedures, public health problems require attention from the scientific community. Among the main pathologies in Brazil and worldwide, nosocomial infections, such as infections caused by bacteria, have become more potent due to the increase in bacterial resistance. These increases are characterized by natural and evolutionary processes observed in microorganisms as responses to environmental stimuli, which are intensified by the incorrect use of antibiotics, leading to bacterial resistance to the usual drugs. In the next 30 years, the number of deaths related to bacterial infections might reach 10 million people worldwide and 392,000 in Latin America alone annually [1-4].

Bacteria can present two forms of life: the first is planktonic, characterized by independent growth, that is, decoupled from a solid structure or from other organisms such as fungi or even other bacteria, this way of life facilitates their proliferation. The second is as biofilms, which form a community involved in an extracellular matrix composed of several biopolymers, such as extracellular polysaccharides, proteins, DNA, and lipids, in addition to the association of other microorganisms, such as fungi $[5,6]$.

The formation and adhesion of surface bacterial biofilms can be reversible or irreversible, depending on the physical-chemical forces present in the environment. It also depends on the mechanisms of regulation of cell density and collective behavior, called quorum sensing, which allow bacteria to synchronize their gene expression for the formation of the biofilm [7-12]. Biofilm formation seems to be related to gene expression and the presence of structures that alter bacterial conformation to the state of biofilm, such as flagella and lashes. The absence of a gene or lack of expression may be directly related to the lack of capacity to form biofilms, even within the same species, depending on different strains [6].

Biofilms provide some benefits to bacteria, including the increased tolerance of such microorganisms to extreme environmental conditions. Furthermore, the exopolysaccharides (EPSs) increase protection against bactericidal agents. This mechanism allows the exchange of genetic material between different species of bacteria and between organisms of the same species, thus facilitating the spread of bacterial resistance, a fact that has aroused interest in the scientific community [12-15].

On the other hand, the bioprospecting of animal toxin molecules with pharmaceutical application has gained attention, since the variety of these compounds offers alternative candidate sources for the production of new antimicrobial and antitumor drugs for the treatment of viral infections, cancer, and parasitic and bacterial infections $[16,17]$. Among these sources, snake venoms have a wide variety of components, where about $90 \%$ of their dry weight is composed of proteins, among which are phospholipases $\mathrm{A}_{2}\left(\mathrm{PLA}_{2}\right)$, enzymatic proteins that generally have low molecular weight. These are responsible for catalyzing the hydrolysis of the 3-sn-phosphoglyceride-dependent calcium 2-acyl ester bond, obtaining lysophospholipids and fatty acid products [18-20].

These enzymes play an important role in the metabolism of lipid molecules and are also related to the production and release of arachidonic acid (AA), a precursor of bioactive lipids that participates in cellular activities, due to the release of compounds such as prostaglandins, thromboxane, and leukotrienes, characterizing a perception of pain and inflammation [20-24]. Indeed, bites caused by snakes from the genus Bothrops show pharmacological effects characteristic of $\mathrm{PLA}_{2}$ action, such as inflammation, local pain, anticoagulant effects, and edema. The viper Bothrops erythromelas is of the greatest medical pharmacological interest $[25,26]$.

The $A_{2}$ phospholipases of snake venoms are similar to each other, but they have different toxicological profiles, such as myotoxicity, neurotoxicity, anticoagulant activity, hemolysis, hyperalgesia, inflammation, edema, cytotoxicity, hypotension, and antimicrobial activity [20,27-31]. In this context, the antibacterial activity already observed for phospholipases has drawn attention to the use of these toxins as an alternative for the production of medicines. Therefore, this work aimed to purify $\mathrm{A}_{2}$ phospholipases of the venom from B. erythromelas and further evaluate their antibacterial and antibiofilm activities. 


\section{Results}

\subsection{Purification and Characterization of $P L A_{2}$ from B. erythromelas}

Following venom extraction and lyophilization, the crude venom was applied to a reverse-phase chromatograph (RP-HPLC) using a C18 column. The crude venom exhibited a protein profile of 14 peaks, eluted along the gradient of buffer B (Figure 1a). Peak 8 showed a retention time of 29.4 min and was eluted with $\sim 40 \%$ of buffer $\mathrm{B}$, corresponding to the $\mathrm{PLA}_{2}$ from B. erythromelas.

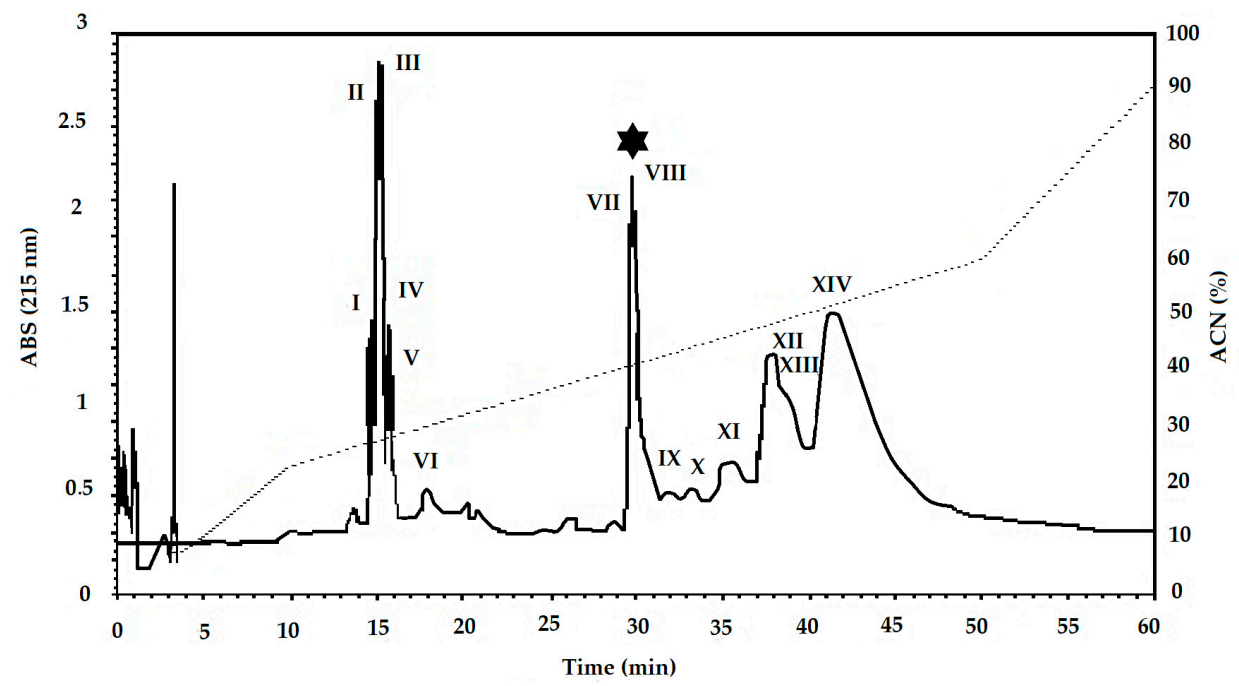

(a)

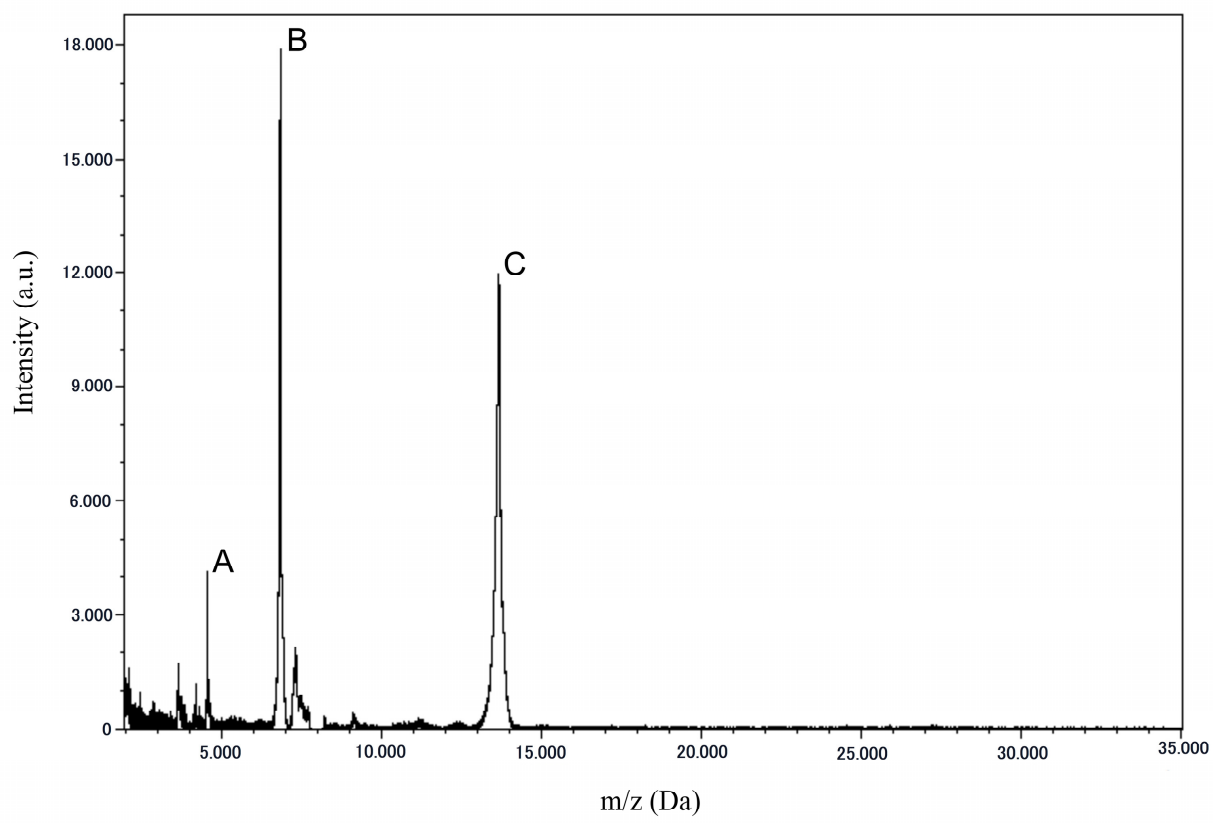

(b)

Figure 1. Phospholipase $\mathrm{A}_{2}\left(\mathrm{PLA}_{2}\right)$ purification from Bothrops erythromelas venom. (a) Reverse-phase chromatographic profile, fractions 1 to 14 , on a C18 column equilibrated with solvent A $(0.1 \%$ TFA in water) and eluted with 5-95\% solvent B (acetonitrile: solvent A, 9:1, v:v) and a flow rate of 2 mL.min ${ }^{-1}$. (b) Fraction 8 (VIII) $\left(^{*}\right)$ analyzed by mass spectrometry; ion mass-to-charge ratios are indicated, demonstrating single $(\mathrm{C})[\mathrm{M}+\mathrm{H}]^{+} 13.6564 \mathrm{Da}$, double $(\mathrm{B})[\mathrm{M}+2 \mathrm{H}]^{2+} 6.8265 \mathrm{Da}$, and triple (A) $[\mathrm{M}+3 \mathrm{H}]^{3+} 4.5499 \mathrm{Da}$ charge states for the same analyte. 
In order to confirm the purity of the collected $\mathrm{PLA}_{2}$, the sample was subjected to analysis in a mass spectrometer (Figure 1b), which generated a spectrum with a mass of $13.6564 \mathrm{Da}$ and the presence of double $[\mathrm{M}+2 \mathrm{H}]^{2+}(6.8265 \mathrm{Da})$ and triple $[\mathrm{M}+3 \mathrm{H}]^{3+}(4.5499 \mathrm{Da})$ charge, confirming the purity of the fraction collected from RP-HPLC.

Figure 2 demonstrates that the $\mathrm{PLA}_{2}$ isoform of $B$. erythromelas venom in a concentration of $0.06 \mu \mathrm{M}$ showed enzymatic activity that was three times more powerful than commercial phospholipase (bovine pancreas phospholipase $\mathrm{A}_{2}$-P9913 Sigma) and the crude venom of the snake, compared to the synthetic substrate acid 4-nitro-3-(octanoyloxy)benzoic acid ( $\left.4 \mathrm{~N}_{3} \mathrm{OBA}\right)$.

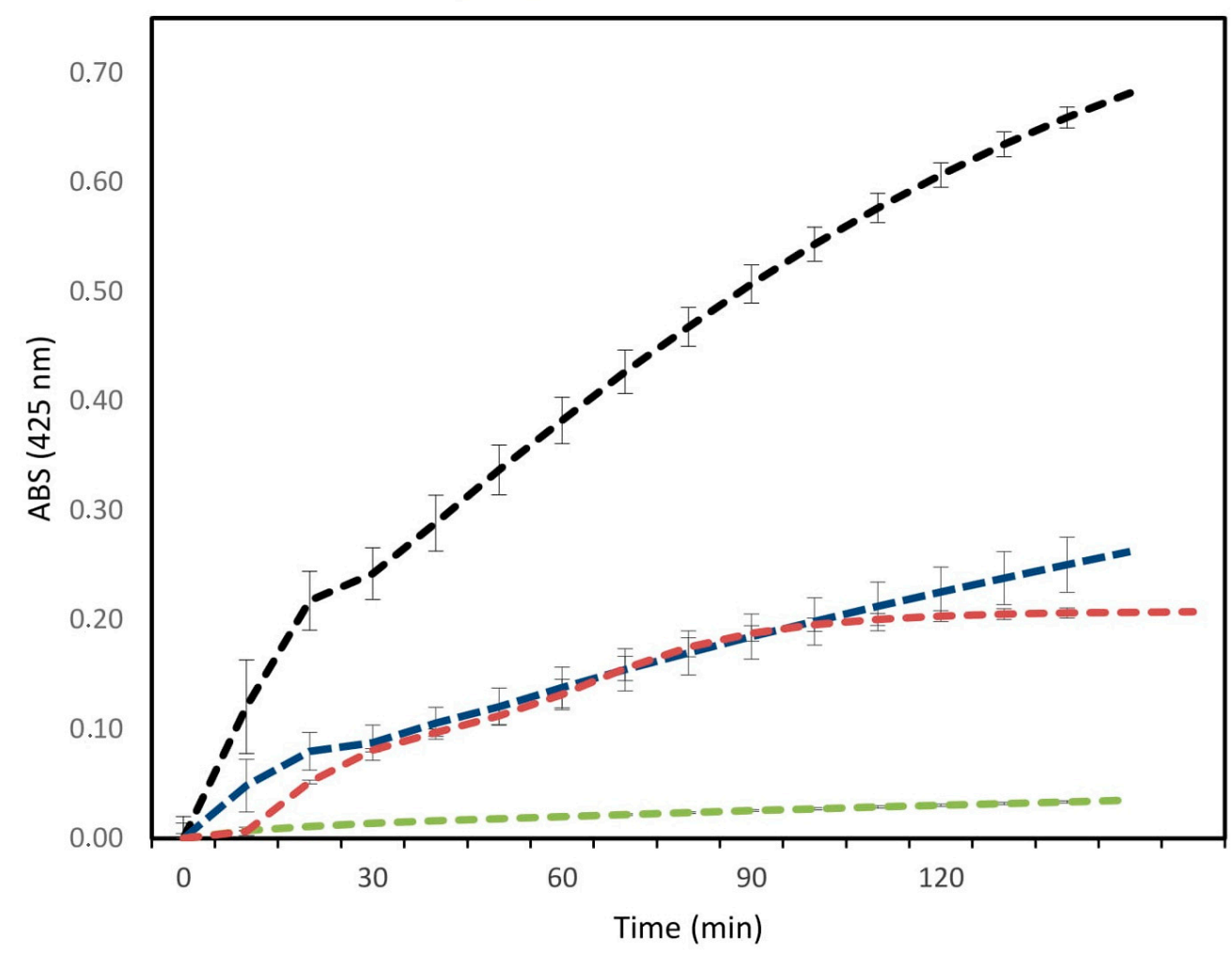

Figure 2. Comparison between activity of the crude venom of B. erythromelas, the purified fraction $\mathrm{PLA}_{2}$, a commercial phospholipase, and the bovine serum albumin (BSA) consumption of substrate $4 \mathrm{~N}_{3} \mathrm{OBA}$ in a concentration of $0.06 \mu \mathrm{M}$. Legend colors: black: PLA 2 isoform; blue: $\mathrm{PLA}_{2}$ commercial; red: crude venom; green: BSA.

Edman's degradation provided an amino acid sequence with $31 \mathrm{~N}$-terminal amino acid residues, with 13 hydrophobic residues and no charge. Subsequently, the sequence was submitted to Basic Local Alignment Search Tool (BLAST), where 96\% homology was observed for three acidic PLA 2 : bpPLA 2 -TXI from Bothrops pauloensis, $\mathrm{sPLA}_{2}$-II from Bothrops diporus, and BE-I-PLA ${ }_{2}$ from B. erythromelas. To compare the sequences, alignment was performed using ClustalW, where it was possible to observe that only the amino acids Trp ${ }^{1}$ and $\mathrm{Asp}^{25}$ in the sequence of our sample are different from the compared sequences, and the $\mathrm{PLA}_{2}$ isoform has one hydrophobic residue more than other sequences, configuring a more hydrophobic property for the isoform PLA 2 (Table 1) [32-34]. 
Table 1. Sequence alignment of the phospholipase $\mathrm{A}_{2}$ isoform with phospholipase activity with BpPLA 2 -TXI, sPLA 2 -II, and BE-I-PLA 2 , using the ClustalW tool. Legend: asterisk = identity.

\begin{tabular}{|c|c|c|c|c|c|}
\hline Species & Access Number & PLA $_{2}$ & Alignment & Homology (\%) & Charge \\
\hline B. erythromelas & - & $\mathrm{PLA}_{2}$ Isoform & WLVQFETLIMKIAGRSGVWYYGSYDCYCGSG & - & 0 \\
\hline B. pauloensis & D0UGJ0.1 & $\mathrm{BpPLA}_{2}-\mathrm{TXI}$ & NLVQFETLIMKIAGRSGVWYYGSYGCYCGSG & 96 & +1 \\
\hline B. diporus & AFJ79208.1 & $\mathrm{sPLA}_{2}-\mathrm{II}$ & NLVQFETLIMKIAGRSGVWYYGSYGCYCGSG & 96 & +1 \\
\hline B. erythromelas & Q2HZ28.1 & BE-I-PLA 2 & 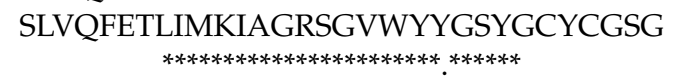 & 96 & +1 \\
\hline
\end{tabular}

The similarity observed in the purified fraction with the phospholipases BpPLA 2 -TXI, sPLA - II, and BE-I-PLA 2 offers reliable indications of an acidic characteristic in our sample. 


\subsection{Hemolytic Activity Assays}

Once purified, we investigated the hemolytic activity of $\mathrm{PLA}_{2}$ from B. erythromelas against murine blood, since the absence of hemolysis is a prerequisite for further biochemical and pharmacological assays. The $\mathrm{PLA}_{2}$ from $B$. erythromelas showed no hemolysis when incubated, even at the maximum concentration assayed, from 1.17 to $37.5 \mu \mathrm{M}$. This result shows the feasibility for carrying out biological tests with the purified fraction.

\subsection{Antibacterial and Antibiofilm Activity}

The tests showed that the purified PLA 2 isoform exerts activity in Gram-positive strains. In the first tests with Staphylococcus aureus ATCC (American Type Culture Collection) 7133623, there was activity at all concentrations tested, with the best concentration being $37.49 \mu \mathrm{M}$, representing $62 \% \pm 17 \%$ of activity, whereas for Escherichia coli ATCC 25922, low activity was observed at the concentration of $37.49 \mu \mathrm{M}$, representing only $12 \% \pm 2 \%$ of activity, however, ciprofloxacin showed the best results in the activity observed in $\mathrm{PLA}_{2}$, as shown in Table 2 and Figure S1 (Supplementary Materials).

Table 2. Antibacterial and antibiofilm activity and $\mathrm{IC}_{50}$ in vitro evaluation for $\mathrm{PLA}_{2}$ against Escherichia coli ATCC 25922, Acinetobacter baumannii 00332126, and Staphylococcus aureus ATCC 7133623 compared to ciprofloxacin antibiotic activity.

\begin{tabular}{|c|c|c|c|c|}
\hline Bacteria & Concentration $(\mu \mathrm{M})$ & Ciprofloxacin (\%) & Activity PLA $(\%)$ & $\mathrm{IC}_{50} \mathrm{PLA}_{2}(\mu \mathrm{M})$ \\
\hline E. coli ATCC 25922 & 37.4 & $97 \pm 16$ & $12 \pm 20$ & - \\
\hline $\begin{array}{c}\text { S. aureus ATCC } \\
7133623\end{array}$ & 37.4 & $90 \pm 18$ & $62 \pm 17$ & 30.2 \\
\hline $\begin{array}{c}\text { A. baumannii } \\
00332126\end{array}$ & 37.4 & 0 & $37 \pm 10$ & - \\
\hline \multicolumn{5}{|l|}{ Biofilm } \\
\hline $\begin{array}{c}\text { A. baumannii } \\
00332126\end{array}$ & 1.17 & $7 \pm 6$ & $53 \pm 11$ & 1.1 \\
\hline
\end{tabular}

The isolated clinical strain of Acinetobacter baumannii 00332126 was then tested. Although it showed greater growth, it also showed better antibacterial activity at concentrations of $37.49 \mu \mathrm{M}$, representing $37 \% \pm 10 \%$ of activity, showing better activity including compared to antibiotic, which was not able to inhibit bacterial growth of A. baumannii. As the S. aureus ATCC 7133623 strain did not present biofilm growth, antibiofilm activity was also tested in A. baumannii 00332126 . The test showed activity at all concentrations through the $\mathrm{PLA}_{2}$ isoform. The best concentration was $1.17 \mu \mathrm{M}$, with $53 \%$ $\pm 11 \%$ of activity, also showing better activity when compared to antibiotic (Table 2 and Figure S1 in Supplementary Materials).

\section{Discussion}

Our results present a PLA 2 with acidic characteristics that showed a homology of $96 \%$ with the only $\mathrm{PLA}_{2}$ already described, so far, for B. erythromelas venom (BE-I-PLA ${ }_{2}$ ). The main difference in the purification of our $\mathrm{PLA}_{2}$ was in the steps used, because in our work we sought to optimize time by applying only one chromatographic step, i.e., RP-HPLC in a C18 column. In this way, a PLA $\mathrm{P}_{2}$ was obtained with a molecular mass of $13.6564 \mathrm{Da}$, whereas for the purification of BE-I-PLA, four steps were applied with different buffers for elution, and column C4 in RP-HPLC, obtaining a PLA 2 with a molecular mass of 13.64957 Da [34].

The use of several steps during the purification of $\mathrm{PLA}_{2}$ from snake venom has been common for a long time. Some studies report the use of at least two stages, such as PLA $\mathrm{A}_{2}$ isolated from the venom of Bothrops alternatus, Bothrops asper, and Bothrops neuwiedi, using two chromatographic stages, where in the RP-HPLC stages, like us, they used column C18 [35-37]. 
Other reports show the use of up to three stages, such as studies involving the species Bothrops atrox and Bothrops jararaca, which were subjected to different stages and buffers. The other purifications mentioned were the use of a C18 column in the RP-HPLC stage, differing only from BE-I-PLA 2 isolated from B. erythromelas $[34,38,39]$.

More recent studies point to a reduction in the chromatographic steps during the purification of $\mathrm{PLA}_{2}$, as in our work. Using the same methodology applied in the present work, a study involving the species B. pauloensis showed the purification of a PLA 2 (BpPLA - TXI), with $96 \%$ homology with our isoform. Confirming that the use of only one step is satisfactory during purification, another study was done with the species Bothrops cotiara, which used a methodology similar to ours and managed to purify a basic PLA 2 with a mass of $13.716 \pm 3$ Da [32,40].

Therefore, the type of solvent involved in the dilution of the lyophilized sample, as well as the methodology applied, in relation to the linear gradient and the separation column, proved to be important factors for the possible purity of the sample in just one chromatographic step. Thus, it is important to establish the best method of purification, optimizing the time spent on research.

Once purified, we subjected the PLA 2 from B. erythromelas to enzymatic assays. The enzymatic profile observed in Figure 2 demonstrated that our purification process yielded a catalytically active $\mathrm{PLA}_{2}$, since a high consumption of the substrate by the purified fraction was observed, indicating a possible Asp ${ }^{49}$ residue, as in the isoform BE-I-PLA 2 reported earlier [34]. Comparing the enzymatic activity of two PLA $\mathrm{P}_{2}$ forms isolated from Bothrops jararacussu (BthTx-I and BjVIII) with a commercial $\mathrm{PLA}_{2}$, and using $4 \mathrm{~N}_{3} \mathrm{OBA}$ as substrate, enzymatic activity was observed. This is a basic characteristic of this type of $\mathrm{PLA}_{2}$, determining a $\mathrm{PLA}_{2} \mathrm{Lys}^{49}$. Likewise, the enzymatic activity of a PLA ${ }_{2}$ from Bothrops neuwiedi urutu, which contains Lys ${ }^{49}$, was absent when the synthetic substrate $4 \mathrm{~N}_{3} \mathrm{OBA}$ was used $[37,41]$. Similarly, studies using the substrate $4 \mathrm{~N}_{3} \mathrm{OBA}$ compared the catalytic activity of a $\mathrm{PLA}_{2}$ (Bmaj-9) isolated from the venom of the snake Bothrops marajoensis with the crude venom of the same snake. They observed that Bmaj-9 also showed catalytic activity at a concentration of $1.46 \mu \mathrm{M}$, higher than that of the snake's crude venom [42].

The $N$-terminal amino acid sequencing for phospholipase showed two different amino acids when compared with another PLA 2 (BpPLA 2 -TXI; sPLA 2 -II and BE-I-PLA $)_{2}$ ). However, the similarity among $N$-terminal sequences was maintained at $96 \%$. The presence of a $\operatorname{Trp}^{1}$ indicates the greater hydrophobicity of the sample, since this amino acid has aromatic characteristics with a relatively non-polar side chain, which also facilitates the absorption of light. The presence of an $\mathrm{Asp}^{25}$ indicates an increase in the acidic characteristic of our sample, since this amino acid is between the two amino acids that have the negatively charged group $\mathrm{R}$ at $\mathrm{pH} 7.0$, thus giving it an acidic property. Asp ${ }^{25}$ also justifies the presence of a null charge in the isolated sequence, since the presence of this amino acid increases the positive charges, making them equal to the negative charges, which are consequently annulled [32-34,43].

In our study, no hemolytic activity was observed for $\mathrm{PLA}_{2}$ from B. erythromelas. The lack of hemolytic activity for a PLA 2 is unusual, but studies speculate that some actions of $\mathrm{PLA}_{2}$ are still not well described, based on the absence of toxicity for some prey. Furthermore, the actions may be related to the evolution of this enzyme, which can be present in the venom gland but not develop its expected toxic activity. Studies with an acidic $\mathrm{PLA}_{2}\left(\mathrm{BmooPLA}_{2}\right)$ isolated from Bothrops moojeni showed a presence of hemolytic activity at $0.07 \mu \mathrm{M}$ [44].

A further study carried out with an acidic PLA 2 isolated from Porthidium nasutum (PnPLA 2 ), displayed hemolytic activity from $0.47 \mu \mathrm{M}$ [45]. Indirect hemolytic activities in sheep blood were also reported for $\mathrm{PLA}_{2}$ from B. alternatus at $47.26 \mu \mathrm{M}$ [35]. However, a study involving the isolation of two PLA (PLA $_{2}-12$ and $\left.\mathrm{PLA}_{2}-17\right)$, from the snake Micrurus fulvius, showed that one of the enzymes showed intravascular hemolytic activity in a mice model, namely PLA $2-17$, while PLA $2-12$ did not show intravascular hemolysis in the same model tested [46]. This last result corroborates our findings.

Our findings show that the isoform purified from the B. erythromelas venom showed $\mathrm{IC}_{50}$ for the Gram-positive strain, whereas for the Gram-negative strains no $\mathrm{IC}_{50}$ was reached at the assayed 
concentration. These data are in accordance with studies where basic the $\mathrm{PLA}_{2}$ isolated from B. marajoensis venom showed loss of inhibitory activity in all tested strains [47].

The PLA 2 Lys $^{49}$ from Lachesis muta venom, also belonging to the Viperidae family, showed antimicrobial activity against S. aureus ATCC 29213 at $0.9 \mu \mathrm{M}$. Similarly, studies of a basic PLA $\mathrm{P}_{2}$ isolated from Daboia russelii (Viperidae), showed better antimicrobial effects for Gram-positive bacteria in comparison with that for Gram-negative bacteria [48,49]. These data corroborate our findings.

It is believed that the antimicrobial activity of $\mathrm{PLA}_{2}$, especially those with basic properties, is related to disturbances of bacterial membrane integrity [37,50,51]. As Gram-negative bacteria have a cell wall with an outer membrane made up of asymmetric lipids, followed by a layer of peptidoglycans, and an inner membrane made up of phospholipids, it is well established that this conformation makes it difficult for some drugs to enter. This can also be seen in the activity of $\mathrm{PLA}_{2}$, since the outer membrane is naturally resistant to the action of PLA 2 [16].

Otherwise, Gram-positive bacteria have only one layer of peptidoglycans followed by an internal cell membrane, showing that they are more susceptible to the action of a PLA 2 . Thus, the low bactericidal activity of some phospholipases in Gram-negative bacteria compared to the activity observed in Gram-positive bacteria is probably related to the structure of their cell wall, which makes Gram-negative bacteria more resistant to the action of toxic compounds [16,52].

Commercial polypeptide antibiotics, such as bacitracin, act on Gram-positive bacteria, inhibiting the synthesis of the bacterial cell wall, preventing the addition of amino acids and nucleotides to the cell wall. Based on the mechanism of action observed in polypeptide antibiotics, it is believed that such proteins should act similarly to these antibiotics in the tested bacteria [53,54].

Research involving the participation of bioactive molecules from several organisms, such as microalgae, plants, and animals, against biofilms is ongoing. These molecules have several pharmacological and toxicological actions that can be used as an alternative for production of drugs that help in the treatment of infections caused by microorganisms, an emerging problem in the human population, also caused by biofilm formation $[55,56]$.

There are several molecular mechanisms involved in the formation of biofilms between species and between strains of bacteria. It is known that a determining factor for the formation of biofilms is the presence of a disturbance or stress caused by bacteria, as well as the presence of proteins or genes that provide for the formation of these matrices. This is observed in S. aureus strains, which have as a determinant for the formation of biofilm the presence of Operon ICA (The intercellular adhesion), or even the formation of a biopolymer essential for the formation of biofilm in this species, such as $\mathrm{N}$-acetyl glucosamine [6,57].

In our experiments, however, we observed that the S. aureus ATCC 7133623 strain is not capable of forming biofilms. For this is reason, antibiofilm assays were carried out only with A. baumannii 00332126 .

A study involving the purification of a venom fraction from Naja ashei, showed antibiofilm activity against a clinical isolate of Staphylococcus epidermidis. In the isolated fraction (F2), the authors report the presence of $\mathrm{PLA}_{2}$, in addition to other proteins such as 3FTx and LAAO, they also believe that an antibiofilm activity is performed by $\mathrm{PLA}_{2}$, considering that this enzyme is successful for antibacterial activities [58]. This result corroborates with our findings.

Similarly, studies involving an antimicrobial peptide isolated from Naja atra (NA-CATH) showed a 50\% reduction in the biofilm formation of the bacterium Burkholderia thailandensis at a concentration of $0.22 \mu \mathrm{M}$, indicating the proven pharmacological potential of snake venoms organic molecules, corroborating the findings, since they have identified a relevant reduction in the biofilm formation of A. baumannii 00332126 [59].

The antimicrobial peptide Cath-A, purified from Bungarus fasciatus (Elapidae), also reduced A. baumannii biofilm formation at $\geq 2.2 \mu \mathrm{M}$. At a higher concentration $(\geq 17.6 \mu \mathrm{M})$, Cath-A destroys almost all cells adhering to the biofilm. Further studies with synthetic antimicrobial peptides showed antibiofilm activity against Pseudomonas aeruginosa and $A$. baumannii with $\mathrm{IC}_{50}$ and $\mathrm{IC}_{90} 4$ and $8 \mu \mathrm{M}$, respectively $[60,61]$. 
In antibiofilm tests with C-type lectins isolated from B. jararacussu venom, an $\mathrm{IC}_{50}$ at a concentration of $6.67 \mu \mathrm{M}$ was observed for S. aureus and S. epidermidis, but the protein was unable to interfere in bacterial growth [62]. Similarly, a study involving B. moojeni isolated molecules showing a reduction in biofilm formation, without influencing bacterial growth [63].

In our studies, growth reduction of the biofilm was obtained from the lowest concentration tested. We observed that the achieved antibiofilm activity was about $20 \%$ more concentrated in the enzyme activity of the molecule, indicating a strong interaction between the enzyme and its specific substrate, in view of its low concentration. The reported activity, however, is unusual for acidic PLA, since antibacterial activity is often present in basic $\mathrm{PLA}_{2}$, as previously reported. This may explain the activity in biofilm and bacteria at concentrations starting at 20\% higher than the enzyme activity of the molecule [47].

This is the first report of an isoform of $\mathrm{PLA}_{2}$ that exhibits antibiofilm activity isolated from a snake of the Viperidae family in the literature, demonstrating how molecules from biological sources can contribute to research regarding bacterial infections, acting as an important source of molecules capable of reducing or eradicating biofilms. The PLA 2 from B. erythromelas, purified by our group, is safe for further biological assays, since no hemolytic activity was noticed against murine erythrocytes. These findings emphasize the importance of bioprospection studies with molecules from animal toxins, especially snakes, to control bacterial biofilms, contributing to advances in the control of infections caused by these microorganisms.

\section{Conclusions}

The purification of the $\mathrm{PLA}_{2}$ isoform from B. erythromelas venom using a single chromatographic step was reported, resulting in protein with $13.6564 \mathrm{Da}$. The amino-terminal portion of the PLA 2 isoform showed $96 \%$ of identity with another $\mathrm{PLA}_{2}$ previously described. Beyond the high enzymatic activity, no hemolytic activity was observed against murine erythrocytes. Notable antibiofilm activity was seen against $A$. baumannii clinical isolates at a low concentration. These findings confirm that purified molecules from snake venoms possess several biological and pharmacological properties. It is therefore necessary to develop basic research around these components, aiming to develop new drugs for the treatment of various diseases that affect human health.

\section{Methods}

\subsection{B. erythromelas Venom Extraction}

B. erythromelas venom was collected from 5 adult specimens in captivity at the Zoo for Reptiles of the Caatinga, located in the municipality of Puxinanã, metropolitan region of Campina Grande, state of Paraiba.

After lyophilization, the venom was kept at $-20^{\circ} \mathrm{C}$ until use. The samples used are registered with the Genetic Heritage Management Council (SisGen) under the register: A883C5B.

\subsection{Quantification of Venom Proteins}

After diluting the lyophilized sample in ultrapure water, the Bradford method (1976), was carried out to quantify the proteins present in the purified fraction. Serial dilutions of the sample were used. As standard for these concentrations, bovine serum albumin (BSA) was used in the same concentration as the purified sample. All samples were tested in triplicate [64].

\subsection{Purification of Venom Proteins}

The crude venom was subjected to high-performance liquid chromatography (Waters and 2695 Separations Module) in a C18 column (Xterra MS $5 \mu \mathrm{m}-4.6 \times 250 \mathrm{~mm}$ column). The solvent system was composed of $0.1 \%$ trifluoroacetic acid (TFA) in $\mathrm{H}_{2} \mathrm{O}$ (Solvent A) and $0.1 \%$ TFA in acetonitrile (Solvent B) in a flow of $2 \mathrm{~mL} \cdot \mathrm{min}^{-1}$ and a linear gradient of 5-95\% acetonitrile, for $60 \mathrm{~min}$. Protein 
peaks were monitored at 216 and $280 \mathrm{~nm}$. The fractions presented in the graphical representation were collected and lyophilized. Subsequently, the fraction with phospholipase activity was selected to be subjected to the mass spectrometer.

\subsection{Phospholipase Activity}

To analyze the phospholipase activity of B. erythromelas venom, the methodology described by Holzer and Mackessy (1996) was used, with changes made by Serino-Silva et al. (2014) [65,66].

The substrate for reaction, 4-nitro-3-(octanoyloxy) benzoic acid $\left(4 \mathrm{~N}_{3} \mathrm{OBA}\right.$, Enzy Life Science, Farmingdale, NY, USA) was used. As a positive control, a commercial phospholipase with a concentration of $0.06 \mu \mathrm{M}\left(1 \mathrm{mg} \cdot \mathrm{mL}^{-1}\right)$ (bovine pancreas phospholipase A2-P9913 Sigma) was prepared, and BSA was used as negative protein control, at the same concentration.

\subsection{Mass Spectrometry}

To measure the molecular mass of the selected fraction, a matrix-assisted ionization time-of-flight (MALDI-ToF) mass spectrometer (AutoFlex III) Smartbeam (Bruker Daltonics, Bremen, Germany) controlled by Flex Control 3.0 software was used (Bruker Daltonics, Bremen, Germany). A $0.37 \mu \mathrm{M}$ sample was solubilized in Ultrapure water, mixed (1:1 v:v) in a saturated solution of sinapinic acid, as matrix, and applied to the target plate (Bruker Daltonics, Bremen, Germany) to dry at room temperature. The compound had its molecular mass obtained in the positive linear mode after external calibration, with Protein Calibration Standard (Bruker Daltonics, Bremen, Germany). The MALDI-ToF spectra were processed with Flex Analysis 3.0 software (Bruker Daltonics, Bremen, Germany).

\subsection{Amino-Terminal Sequencing of $\mathrm{PL} A_{2}$ from B. erythromelas}

The amino-terminal sequencing was obtained through Edman's degradation, using an automatic Shimadzu PPSQ-31B/33B, initially calibrated with the PTH-amino acid mixture standard. A sample of the purified $\mathrm{PLA}_{2}$ was resuspended in $37 \%$ acetonitrile and applied onto a nitrocellulose membrane (PVDF) and dried under nitrogen flow. According to the manufacturer's recommendations, phenyl thiohydantoin amino acids were detected after separation on an RP-HPLC C18 column $(4.6 \times 250 \mathrm{~mm})$. The resulting sequences were applied to the CAST protein BLAST search (BLASTP 2.8.0+) and the significant sequences were aligned using ClustalW 1.2.4.

\subsection{Hemolysis Test}

Erythrocytes of Mus musculus were used for the tests, approved by the ethics committee of the Catholic University Dom Bosco (UCDB) under registration no. 014/2018.

The collected blood was stored at $4{ }^{\circ} \mathrm{C}$ until use. The cells were washed three times with $50 \mathrm{mM}$ phosphate buffer, $\mathrm{pH}$ 7.4. To the erythrocyte suspension was added the fraction of B. erythromelas venom referring to phospholipase at a concentration of $0.07 \mu \mathrm{M}$, in serial dilution of 1.17 to $37.49 \mu \mathrm{M}$ in a final volume of $100 \mathrm{~mL}$. The samples were incubated at room temperature for $60 \mathrm{~min}$. After centrifugation at $3000 \mathrm{rpm}$, hemoglobin release was monitored by reading the absorbance of the supernatant at $425 \mathrm{~nm}$ in a SpectraMax microplates readers (Thermo Fisher Scientific Oy, Vantaa, Finland). To control hemolysis, erythrocytes suspended in $5 \times 10^{4} \mu \mathrm{M}$ phosphate buffer, $\mathrm{pH} 7.4$ were used; as a positive control (100\% erythrocyte lysis), a 1\% (by volume) solution of triton X-100 dissolved in distilled water was used to replace the venom fraction. The tests were performed in triplicate [67].

\subsection{Antibacterial Activity}

Strains of E. coli ATCC 25922, S. aureus ATCC 7133623, and A. baumannii 00332126 (a resistant clinical isolate) were used. For the antibacterial tests, a purified fraction of the venom of the snake B. erythromelas with phospholipase activity was used. The tests to observe the antibacterial activity were performed according to the protocol described by CLSI (Clinical and Laboratory Standards Institute), 
using the 96-well microplate dilution method. Three technical replicates were organized on the microplates at a final bacterial concentration of $2.5 \times 10^{5}$ CFU.mL $\mathrm{mL}^{-1}$ (colony forming unit). The samples were tested in concentrations ranging from 1.17 to $37.49 \mu \mathrm{M}$. For positive control, the antibiotic ciprofloxacin was used in the same concentrations as the samples, while the bacterial suspension in MHB (Mueller-Hinton Broth) was used as a negative control [68].

\subsection{Antibiofilm Activity}

Basal Medium 2 (BM2) was used to analyze the biofilm formation. Bacterial cultures of A. baumannii 00332126, proven to be clinical isolate resistant, were used. As bacterial suspensions, they were inoculated into 96-well round-bottom plates, including samples from serial dilutions from 1.17 to $37.49 \mu \mathrm{M}$. As negative control, only bacteria were used in the BM2 medium, and as a positive control, the antibiotic ciprofloxacin was used in the same concentrations as the sample. To analyze the growth of planktonic cells, an absorbance of $600 \mathrm{~nm}$ was used [69,70].

To assess for biofilm formation, performed as described by Naves et al., 2019, the biofilm formation was read at an absorbance of $595 \mathrm{~nm}$. All absorbance readings were performed with the Multiskan GO microplate reader (Thermo Scientific). All tests were performed in triplicate [71].

Supplementary Materials: The following are available online at http://www.mdpi.com/2072-6651/12/9/606/s1, Figure S1: Antibacterial and antibiofilm activity of the PLA2 isoform.

Author Contributions: E.N. contributed to the work by carrying out all experiments and writing the article; B.F. contributed to the work by teaching techniques such as Bradford, RP-HPLC, and phospholipase activity, following the experiments with the lead author; E.B. contributed to the research by assisting in the antifilm tests; T.F. contributed by helping with the antibacterial test; C.d.O. assisted by carrying out the amino acid sequencing by the E.D. method; N.V. contributed with MALD-ToF; A.d.F.J. contributed by evaluating the writing and supervising students, O.F. contributed by evaluating the writing and supervising students; M.d.M. contributed with the Edman Degradation method; L.M. contributed as a co-advisor, providing space at the S-Inova Laboratory of the Catholic University Dom Bosco, and following the tests performed, as well as correcting the writing of this article; K.L., as a work advisor, contributed in helping with the formation of the objectives and in the development of the experimental design of the research, as well as supervising the writing of this article, making the necessary contributions. All authors have read and agreed to the published version of the manuscript.

Funding: This research was funded by the agency CAPES (Coordination for the Improvement of Higher Education Personnel), https://www.capes.gov.br/.

Acknowledgments: To the research funding agency CAPES (Coordination for the Improvement of Higher Education Personnel) for the scholarship during the period of this work. To the Federal University of Paraiba and the Catholic University Don Bosco for welcoming the first author as a student during this research.

Conflicts of Interest: The funders had no role in the design of the study; in the collection, analyses, or interpretation of data; in the writing of the manuscript; or in the decision to publish the results.

\section{References}

1. Livermore, D.M. Minimizing antibiotic resistance. Lancet Infect. Dis. 2005, 5, 450-459. [CrossRef]

2. Loureiro, R.J.; Roque, F.; Rodrigues, A.T.; Herdeiro, M.T.; Ramalheira, E. O uso de antibióticos e as resistências bacterianas: Breves notas sobre a sua evolução. Rev. Port. Saúde Pública 2016, 34, 77-84. [CrossRef]

3. World Health Organization. Containing Antimicrobial Resistance; WHO: Geneva, Switzerland, 2018; Available online: https://www.who.int/antimicrobial-resistance/en/ (accessed on 23 June 2019).

4. Prevenção e Controle de Infecções e de Resistência aos Antimicrobianos-2017: Programa de Prevenção e Controle de Infecções e de Resistência aos Antimicrobianos 45. Available online: https://www.sns.gov.pt/wpcontent/uploads/2017/12/DGS_PCIRA_V8.pdf (accessed on 15 January 2019).

5. Costerton, J.W.; Irvin, R.T.; Cheng, K.J. The Bacterial Glycocalyx in Nature and Disease. Annu. Rev. Microbiol. 1981, 35, 299-324. [CrossRef]

6. López, D.; Vlamakis, H.; Kolter, R. Biofilms. Cold Spring Harb. Perspect. Biol. 2010, 2, 1-11. [CrossRef] [PubMed]

7. Donlan, R.M.; Costerton, J.W. Biofilms: Survival mechanisms of clinically relevant microorganisms. Clin. Microbiol. Rev. 2002, 15, 167-193. [CrossRef] [PubMed] 
8. Oliveira, M.M.M.; Brugnera, D.F.; Piccoli, R.H. Biofilmes microbianos na indústria de alimentos: Uma revisão. Rev. Inst. Adolfo Lutz 2010, 69, 277-284.

9. Renner, L.D.; Weibel, D.B. Physicochemical regulation of biofilm formation. MRS Bull. 2011, 36, $347-355$. [CrossRef] [PubMed]

10. West, S.A.; Winzer, K.; Gardner, A.; Diggle, S.P. Quorum sensing and the confusion about diffusion. Trends Microbiol. 2012, 20, 586-594. [CrossRef]

11. Trentin, D.; Giordani, R.; Macedo, A. Biofilmes bacterianos patogênicos: Aspectos gerais, importância clínica e estratégias de combate. Rev. Lib. 2013, 14, 213. [CrossRef]

12. Rabin, N.; Zheng, Y.; Opoku-Temeng, C.; Du, Y.; Bonsu, E.; Sintim, H.O. Biofilm formation mechanisms and targests for developing antibiofim agents. Future Med. Chem. 2015, 7, 493-512. [CrossRef]

13. Costerton, L.W.; Lewandowski, Z.; Debeer, D.; Caldwell, D.; Korber, D.; James, G. Biofilms, the customized microniche. J. Bacteriol. 1994, 176, 2137-2142. [CrossRef] [PubMed]

14. Donlan, R.M. Biofilms: Microbial life on surfaces. Emerg. Infect. Dis. 2002, 8, 881-890. [CrossRef] [PubMed]

15. Chandra, J.; Mukherjee, P.K. Candida Biofilms: Development, Architecture, and Resistance. Microbiol. Spectr. 2015, 3, 1-24. [CrossRef] [PubMed]

16. Nevalainen, T.J.; Graham, G.G.; Scott, K.F. Antibacterial actions of secreted phospholipases A2. Rev. Biochim. Biophys. Acta 2008, 1781, 1-9. [CrossRef] [PubMed]

17. Samy, R.P.; Gopalakrishnakone, P.; Chow, V.T.K.; Ho, B. Viper metalloproteinase (Agkistrodon halyspallas) with antimicrobial activity against multi-drug resistant human pathogens. J. Cell Physiol. 2008, 216, 54-68. [CrossRef]

18. Moreira, V.; De Castro Souto, P.C.; Ramirez Vinolo, M.A.; Lomonte, B.; Gutiérrez, J.M.; Curi, R.; Teixeira, C. A catalytically-inactive snake venom Lys49 phospholipase $\mathrm{A}_{2}$ homolog induces expression of cyclooxygenase- 2 and production of prostaglandins through selected signaling pathways in macrophages. Eur. J. Pharmacol. 2013, 708, 68-79. [CrossRef]

19. Dias, R.G.; Sampaio, S.C.; Sant'anna, M.B.; Cunha, F.Q.; Gutiérrez, J.M.; Lomonte, B.; Cury, Y.; Picolo, G. Articular inflammation induced by an enzymatically-inactive Lys49 phospholipase A2: Activation of endogenous phospholipases contributes to the pronociceptive effect. J. Venom. Anim. Toxins Trop. Dis. 2017, 23, 1-13. [CrossRef]

20. Vindas, J.; Carrera, Y.; Lomonte, B.; Gutiérrez, J.M.; Calvete, J.J.; Sanz, L.; Fernández, J. A novel pentameric phospholipase $\mathrm{A}_{2}$ myotoxin (PophPLA 2 ) from the venom of the pit viper porthidium ophryomegas. Int. J. Biol. Macromol. 2018, 118, 1-8. [CrossRef]

21. Scott, D.L.; White, S.P.; Otwinowski, Z.; Yuan, W.; Gelb, M.H.; Singler, P.B. Interfacial catalysis: The mechanism of phospholipase $\mathrm{A}_{2}$. Science 1990, 250, 1541-1546. [CrossRef]

22. Schaloske, R.H.; Dennis, E.A. The phospholipase A2 superfamily and its group numbering system. Biochim. Biophys. Acta 2006, 1761, 1246-1259. [CrossRef]

23. De Maria, L.; Vind, J.; Oxenboll, K.M.; Svendsen, A.; Patkar, S. Phospholipases and their industrial applications. Appl. Microbiol. Biotechnol. 2007, 74, 290-300. [CrossRef] [PubMed]

24. Gutiérrez, J.M.; Rucavado, A.; Chaves, F.; Díaz, C.; Escalante, T. Experimental pathology of local tissue damage induced by Bothrops asper snake venom. Toxicon 2009, 54, 958-975. [CrossRef]

25. Jorge, R.J.B.; Monteiro, H.S.; Gonçalves-Machado, L.; Guarnieri, M.C.; Ximenes, R.M.; Borges-Nojosa, D.M.; Luna, K.P.; Zingali, R.B.; Corrêa-Netto, C.; Gutiérrez, J.M.; et al. Venomics and antivenomics of Bothrops erythromelas from five geographic populations within the Caatinga ecoregion of northeastern Brazil. J. Proteom. 2015, 30, 93-114. [CrossRef] [PubMed]

26. Nery, N.M.; Luna, K.P.O.; Fernandes, C.F.C.; Zuliani, J.P. An overview of Bothrops erythromelas venom. Rev. Soc. Bras. Med. Trop. 2016, 49, 680-686. [CrossRef]

27. Kini, R.M.; Evans, H.J. A model to explain the pharmacological effects of snake venom phospholipases $\mathrm{A}_{2}$. Toxicon 1989, 27, 613-635. [CrossRef]

28. Kini, R.M. Excitement ahead: Structure, function and mechanism of snake venom phospholipase $\mathrm{A}_{2}$ enzymes. Toxicon 2003, 42, 827-840. [CrossRef]

29. Soares, A.; Fontes, M.; Giglio, J. Phospholipase $A_{2}$ Myotoxins from Bothrops Snake Venoms: Structure-Function Relationship. Curr. Org. Chem. 2004, 8, 1677-1690. [CrossRef] 
30. Montecucco, C.O.; Rossetto, O.; Caccin, P.; Rigoni, M.; Carli, L.; Morbiato, L.; Muraro, L.; Paoli, M. Different mechanisms of inhibition of nerve terminals by botulinum and snake presynaptic neurotoxins. Toxicon 2009, 54, 561-564. [CrossRef]

31. Gutiérrez, J.M.; Lomonte, B. Phospholipases $\mathrm{A}_{2}$ : Unveiling the secrets of a functionally versatile group of snake venom toxins. Toxicon 2013, 62, 27-39. [CrossRef]

32. Rodrigues, R.S.; Boldrini-França, J.; Fonseca, F.P.; De La Torre, P.; Henrique-Silva, F.; Sanz, L.; Calvete, J.J.; Rodrigues, V.M. Combined snake venomics and venom gland transcriptomic analysis of Bothropoides pauloensis. J. Proteom. 2012, 75, 2707-2720. [CrossRef]

33. Yunes Quartino, P.J.; Barra, J.L.; Fidelio, G.D. Cloning and functional expression of secreted phospholipases $\mathrm{A}_{2}$ from Bothrops diporus (Yarará Chica). Biochem. Biophys. Res. Commun. 2012, 427, 321-325. [CrossRef] [PubMed]

34. Modesto, J.C.A.; Spencer, P.J.; Fritzen, M.; Valença, R.C.; Oliva, M.L.V.; Silva, M.B.; Chudzinski-Tavassi, A.M.; Guarnieri, M.C. BE-I-PLA $A_{2}$, a novel acidic phospholipase $\mathrm{A}_{2}$ from Bothrops erythromelas venom: Isolation, cloning and characterization as potent anti-platelet and inductor of prostaglandin $\mathrm{I}_{2}$ release by endothelial cells. Biochem. Pharmacol. 2006, 72, 377-384. [CrossRef] [PubMed]

35. Garcia Denegri, M.E.; Acosta, O.C.; Huancahuire-Veja, S.; Martins-De-Souza, D.; Marangoni, S.; Maruñak, S.L.; Teibler, G.P.; Leiva, L.C.; Ponce-Soto, L.A. Isolation and functional characterization of a new acidic PLA 2 Ba SpII RP4 of the Bothrops alternatus snake venom from Argentina. Toxicon 2010, 56, 64-74. [CrossRef] [PubMed]

36. Pereanez, J.A.; Quintana, J.C.; Alarcón, J.C.; Núñez, V. Isolation and functional characterization of a basic phospholipase $\mathrm{A}_{2}$ from Colombian Bothrops asper venom. Vitae Rev. La Fac. Química Farm. 2014, 21, $38-48$.

37. Corrêa, E.A.; Kayano, A.M.; Diniz-Sousa, R.; Setúbal, S.S.; Zanchi, F.B.; Zuliani, J.P.; Matos, N.B.; Almeida, J.R.; Resende, L.M.; Marangoni, S.; et al. Isolation, structural and functional characterization of a new Lys49 phospholipase $\mathrm{A}_{2}$ homologue from Bothrops neuwiedi urutu with bactericidal potential. Toxicon 2016, 115, 13-21. [CrossRef] [PubMed]

38. Menaldo, D.L.; Jacob-Ferreira, A.L.; Bernardes, C.P.; Cintra, A.C.O.; Sampaio, S.V. Purification procedure for the isolation of a P-I metalloprotease and an acidic phospholipase $\mathrm{A}_{2}$ from Bothrops atrox snake venom. J. Venom. Anim. Toxins Trop. Dis. 2015, 21,1-14. [CrossRef]

39. Cedro, R.C.A.; Menaldo, D.L.; Costa, T.R.; Zoccal, K.F.; Sartim, M.A.; Santos-Filho, N.A.; Faccioli, S.H.; Sampaio, S.V. Cytotoxic and inflammatory potential of a phospholipase A2 from Bothrops jararaca snake venom. J. Venom. Anim. Toxins Trop. Dis. 2018, 24, 1-14. [CrossRef]

40. De Roodt, A.; Fernández, J.; Solano, D.; Lomonte, B. A myotoxic Lys49 phospholipase $\mathrm{A}_{2}$-homologue is the major component of the venom of Bothrops cotiara from Misiones, Argentine. Toxicon 2018, 148, 143-148. [CrossRef]

41. Fagundes, F.H.R.; Aparicio, R.; Dos Santos, M.L.; Diz, E.B.S.; Oliveira, S.C.B.; Toyama, D.O.; Toyama, M.H. A Catalytically Inactive Lys49 PLA 2 Isoform from Bothrops jararacussu venom that Stimulates Insulin Secretion in Pancreatic Beta Cells. Protein Pept. Lett. 2011, 18, 1133-1139. [CrossRef]

42. Galbiatti, C.; Rocha, T.; Randazzo-Moura, P.; Ponce-Soto, L.A.; Marangoni, S.; Cruz-Höfling, M.A.; Rodrigues-Simioni, L. Pharmacological and partial biochemical characterization of Bmaj-9 isolated from Bothrops marajoensis snake venom. J. Venom. Anim. Toxins Trop. Dis. 2012, 18, 62-72. [CrossRef]

43. Fernandes, C.A.H.; Borges, R.J.; Lomonte, B.; Fontes, M.R.M. A structural-based proposal for a comprehensive myotoxic mechanism of phospholipase $\mathrm{A}_{2}$-like proteins from viperid snake venoms. Biochim. Biophys. Acta 2014, 1844, 2265-2276. [CrossRef]

44. Silveira, L.B.; Marchi-Salvador, D.P.; Santos-Filho, N.A.; Silva, F.P., Jr.; Marcussi, S.; Fuly, A.L.; Nomizo, A.; Da Silva, S.L.; Stábeli, R.G.; Arantes, E.C.; et al. Isolation and expression of a hypotensive and anti-platelet acidic phospholipase A2 from Bothrops moojeni snake venom. J. Pharm. Biomed. Anal. 2013, 73, 35-43. [CrossRef] [PubMed]

45. Vargas, L.J.; Londoño, M.; Quintana, J.C.; Rua, C.; Segura, C.; Lomonte, B.; Núñez, V. An acidic phospholipase $\mathrm{A}_{2}$ with antibacterial activity from Porthidium nasutum snake venom. Comp. Biochem. Physiol. B Biochem. Mol. Biol. 2012, 161, 341-347. [CrossRef] [PubMed] 
46. Fernández, M.L.; Quartino, P.Y.; Arce-Bejarano, R.; Fernadez, J.; Camacho, L.F.; Gutiérrez, J.M.; Kuemmel, D.; Fidelio, G.; Lomonte, B. Intravascular hemolysis induced by phospholipase $\mathrm{A}_{2}$ from the venom of the Eastern coral snake, Micrurus fulvius: Functional profiles of hemolytic and non-hemolytic isoforms. Toxicol. Lett. 2018, 286, 39-47. [CrossRef] [PubMed]

47. Costa-Torres, A.F.; Dantas, R.T.; Toyama, M.H.; Diz Filho, E.; Zara, F.J.; Rodrigues De Queiroz, M.G.; Pinto Nogueira, N.A.; Rosa De Oliveira, M.; De Oliveira Toyama, D.; Monteiro, H.S.; et al. Antibacterial and antiparasitic effects of Bothrops marajoensis venom and its fractions: Phospholipase $\mathrm{A}_{2}$ and L-aminoacid oxidase. Toxicon 2010, 55, 795-804. [CrossRef] [PubMed]

48. Diniz-Sousa, R.; Caldeira, C.A.S.; Kayano, A.M.; Paloschi, M.V.; Pimenta, D.C.; Simôes-Silva, R.; Ferreira, A.S.; Zanchi, F.B.; Matos, N.B.; Grabner, F.P.; et al. Identification of the Molecular Determinants of the Antibacterial Activity of LmutTX, a Lys49 Phospholipase $\mathrm{A}_{2}$ Homologue Isolated from Lachesis muta muta Snake Venom (Linnaeus, 1766). Basic Clin. Pharm. Toxicol. 2018, 122, 413-423. [CrossRef]

49. Sudharshan, S.; Dhananjaya, B.L. Antibacterial potential of a basic phospholipase A2 (VRV-PL-VIIIa) from Daboia russelii pulchella (Russell's viper) venom. J. Venom. Anim. Toxins Trop. Dis. 2015, 21, 1-8. [CrossRef]

50. Yan, X.M.; Zhang, S.Q.; Chang, Q.; Liu, P.; Xu, J.S. Antibacterial and antifungal effects of Agkistrodon halys Pallas: Purification of its antibacterial protein-LAO. Shi Yan Sheng Wu Xue Bao 2000, 33, 309-316.

51. Soares, A.M.; Guerra-Sa, R.; Borja-Oliveira, C.R.; Rodrigues, V.M.; Rodrigues-Simioni, L.; Rodrigues, V.; Fontes, M.R.M.; Lomonte, B.; Gutierrez, J.M.; Giglio, J.R. Structural and functional characterization of BnSP-7, a Lys49 myotoxic phospholipase $\mathrm{A}_{2}$ homologue from Bothrops neuwiedi pauloensis venom. Arch. Biochem. Biophys. 2000, 378, 201-209. [CrossRef]

52. Furtado, M.F.D. Biological and immunological properties of the venom of Bothrops alcatraz, and endemic species of pitviper from Brazil. Comp. Biochem. Physiol. 2005, 141, 117-123. [CrossRef]

53. Raetz, C.R.H.; Whitfield, C. Lipopolysaccharide Endotoxins. Annu. Rev. Biochem. 2002, 71, 635-700. [CrossRef] [PubMed]

54. De Nemacetin-Anvisa, B. Available online: http://www.anvisa.gov.br/datavisa/fila_bula/frmVisualizarBula. asp?pNuTransacao=21331052016\&pIdAnexo=3776379 (accessed on 10 September 2019).

55. Villa, F.; Cappitelli, F. Plant-derived bioactive compounds at sub-lethal concentrations towards smart biocide-free antibiofilm strategies. Phytochem. Rev. 2013, 12, 245-254. [CrossRef]

56. Lauritano, C.; Andersen, J.H.; Hansen, E.; Albrigsten, M.; Escalera, L.; Esposito, F.; Helland, K.; Hanssen, K.; Romano, G.; Ianora, A. Bioactivity Screening of Microalgae for Antioxidant, Anti-Inflammatory, Anticancer, Anti-Diabetes, and Antibacterial Activities. Front. Mar. Sci. 2016, 3, 68. [CrossRef]

57. O'gara, J.P. Ica and beyond: Biofilm mechanisms and regulation in Staphylococcus epidermidis and Staphylococcus aureus. FEMS Microbiol. Lett. 2007, 270, 179-188. [CrossRef]

58. Bocian, A.; Ciszkowicz, E.; Hus, K.K.; Buczkowicz, J.; Lecka-Szlachta, K.; Pietrowska, M.; Petrilla, V.; Petrillova, M.; Legath, L.; Legáth, J. Antimicrobial Activity of Protein Fraction from Naja ashei Venom against Staphylococcus epidermidis. Molecules 2020, 25, 293. [CrossRef]

59. Blower, R.J.; Barksdale, S.M.; Van Hoek, M.L. Snake Cathelicidin NA-CATH and Smaller Helical Antimicrobial Peptides Are Effective against Burkholderia thailandensis. PLoS Negl. Trop. Dis. 2015, 9, 1-16. [CrossRef]

60. Tajbakhsh, M.; Akhavan, M.M.; Fallah, F.; Karimi, A. A Recombinant Snake Cathelicidin Derivative Peptide: Antibiofilm Properties and Expression in Escherichia coli. Biomolecules 2018, 8, 118. [CrossRef]

61. Mohamed, F.M.; Brezden, A.; Mohammad, H.; Chmielewski, J.; Seleem, M.N. A short D-enantiomeric antimicrobial peptide with potent immunomodulatory and antibiofilm activity against multidrug-resistant Pseudomonas aeruginosa and Acinetobacter baumannii. Sci. Rep. 2017, 7, 1-13. [CrossRef]

62. Klein, R.C.; Fabres-Klein, M.H.; De Oliveira, L.L.; Feio, R.N.; Malouin, F.; Ribon, A.D.O.B. A C-Type Lectin from Bothrops jararacussu Venom Disrupts Staphylococcal Biofilms. PLoS ONE 2015, 10, 1-16. [CrossRef]

63. Canhas, I.N.; Heneine, L.G.D.; Fraga, T.; Assis, D.C.S.; Borges, M.H.; Chartone-Souza, E.; Nascimento, A.M.A. Antibacterial activity of different types of snake venom from the Viperidae family against Staphylococcus aureus. Acta Sci. Biol. Sci. 2017, 39, 309-319. [CrossRef]

64. Bradford, M.M. A rapid and sensitive method for the quantification of microgram quantities of protein utilizing the principle of protein dye binding. Anal. Biochem. 1976, 72, 248-254. [CrossRef]

65. Holzer, M.; Mackessy, S. An aqueous endpoint assay of snake venom phospholipase $\mathrm{A}_{2}$. Toxicon 1996, 34, 1149-1155. [CrossRef] 
66. Serino-Silva, C.; Morais-Zani, K.; Toyama, M.H.; Toyama, D.O.; Gaeta, H.H.; Rodrigues, C.F.B.; Aguiar, W.S.; Tashima, A.K.; Grego, K.F.; Tanaka-Azevedo, A.M. Purification and characterization of the first $\gamma$-phospholipase inhibitor ( $\gamma$ PLI) from Bothrops jararaca snake serum. PLoS ONE 2018, 13, 1-16. [CrossRef] [PubMed]

67. Cardoso, M.H.; Ribeiro, S.M.; Nolasco, D.O.; De La Fuente-Núñez, C.; Felício, M.R.; Gonçalves, S.; Mattos, O.C.; Liao, L.M.; Santos, N.C.; Hancock, R.E.W.; et al. A polyalanine peptide derived from polar fish with anti-infectious activities. Sci. Rep. 2016, 6, 1-15. [CrossRef]

68. Hecht, D.W.; Citron, D.M.; Dzink-Fox, J.; Gregory, W.W.; Jacobus, N.V.; Jenkins, S.G.; Rosenblatt, J.E.; Schuetz, A.N.; Wexler, H. Methods for Antimicrobial Susceptibility Testing of Anaerobic Bacteria, Approved Standard, 8th ed.; CLSI Document M11-A8; Clinical and Laboratory Standards Institute: Wayne, PA, USA; Annapolis Junction, MD, USA, 2012; pp. 1-39.

69. De La Fuente-Núnez, C.; Reffuveille, F.; Haney, E.F.; Straus, S.K.; Hancock, R.E.W. Broad-Spectrum Anti-biofilm Peptide That Targets a Cellular Stress Response. PLoS Pathog. 2014, 10, 1-12. [CrossRef]

70. De La Fuente-Núnez, C.; Reffuveille, F.; Mansour, S.C.; Reckseidler-Zenteno, S.L.; Hernández, D.; Brackman, G.; Coenye, T.; Hancock, R.E. D-enantiomeric peptides that eradicate wild-type and multi-drug resistant biofilms and protect against lethal Pseudomonas aeruginosa infections. Chem. Biol. 2015, 22, 196-205. [CrossRef]

71. Naves, P.; Del Prado, G.; Huelves, L.; Gracia, M.; Ruiz, V.; Blanco, J.; Soriano, F. Correlation between virulence factors and in vitro biofilm formation by Escherichia coli strains. Microb. Pathog. 2008, 45, 86-91. [CrossRef]

(C) 2020 by the authors. Licensee MDPI, Basel, Switzerland. This article is an open access article distributed under the terms and conditions of the Creative Commons Attribution (CC BY) license (http://creativecommons.org/licenses/by/4.0/). 